\title{
PENERAPAN MODEL PEMBELAJARAN KOOPERATIF TIPE STUDENT TEAMS - ACHIEVEMENT DIVISION (STAD) UNTUK MENINGKATKAN HASIL BELAJAR SISWA PADA MATA PELAJARAN PEMELIHARAAN MESIN KENDARAAN RINGAN
}

\author{
Faisal Akhmad \\ Fakultas Teknik, Universitas Negeri Yogyakarta \\ e-mail: fais.akhmad09@gmail.com
}

\begin{abstract}
This research aims to increase student learning outcomes of class XI TKR 3 in the PMKR at SMK N 2 Yogyakarta through the application of the cooperative learning model type Student Teams Achievement Division (STAD). This research is Classroom Action Research (CAR). The research carried out in 2 cycles where each cycle was 1 times meeting. The research subject were student of class XII TKR 3 on the Pemeliharaan Mesin Kendaraan Ringan (PMKR) subjects in thr 2019/2020 academic year with a total of 31 students. Data collection is done by test and observation. Data processing is done quantitatively by seeing the implemetation of the cooperative learning model type Student Teams Achievement Division (STAD) and learning outcomes. The succes criteria determined are minimum $75 \%$ of students have reached the Minimum Completion Criteria (MCC) wich is a minimum value of 76,00. The result of this research) is able to increase the learning outcomes of students in class XI TKR 3 in PMKR subjects at SMK N 2 Yogyakarta. Average student learning outcomes increased from data before the action 59,58 to 88,52 in cycle 2. When looking at completeness from the initial data the precentage of students completeness 3,20\% increased to 90,30\%.
\end{abstract}

Keywords: Learning Outcomes, Student Teams Achievement Divison (STAD), PMKR, SMK N 2 Yogyakarta.

\begin{abstract}
Abstrak
Penelitian ini bertujuan untuk meningkatkan hasil belajar siswa kelas XI TKR 3 pada mata pelajaran PMKR di SMK N 2 Yogyakarta melalui penerapan model pembelajaran kooperatif tipe Student Teams Achievement Divison (STAD). Penelitian ini adalah Penelitian Tindakan Kelas (PTK). Penelitian dilaksanakan dalam 2 siklus yang masing - masing siklus terdiri dari 1 kali pertemuan. Subjek penelitiannya adalah siswa kelas XII TKR 3 pada mata pelajaran Pemeliharaan Mesin Kendaraan Ringan (PMKR) semester ganjil tahun ajaran 2019/2020 dengan jumlah 31 siswa. Pengambilan data melalui tes dan observasi. Pengolahan data dilakukan secara kuantitatif dengan melihat pelaksanaan model pembelajaran kooperatif tipe Student Teams Achievement Divison (STAD) dan hasil belajar. Kriteria keberhasilan yang ditentukan adalah $75 \%$ siswa mencapai KKM (Kriteria Ketuntasan Minimal) dengan nilai minimal 76,00. Hasil penelitian ini mampu meningkatkan hasil belajar siswa kelas XI TKR 3 pada mata pelajaran PMKR di SMK N 2 Yogyakarta. Rata - rata hasil belajar siswa meningkat dari data sebelum tindakan 59,58 menjadi 88,52 pada siklus II. Apabila melihat ketuntasannya dari data awal presentase ketuntasan siswa 3,20\% meningkat menjadi 90,30\%.
\end{abstract}

Kata Kunci: Hasil Belajar, Student Teams Achievement Divison (STAD), PMKR, SMK N 2 Yogyakarta

PENDAHULUAN

Jurnal Pendidikan Vokasi Otomotif, Vol 2, Nomor 2, Mei 2020 


\section{Faisal Akhmad}

Perkembangan teknologi pada saat ini mengalami perkembangan yang sangat pesat. Dengan perkembangan teknologi yang pesat ini menuntut kualitas tenaga kerja atau SDM yang lebih tinggi. Selain itu juga, pada saat ini Indonesia sudah memasuki era dimana terjadinya kebebasan produk maupun tenaga kerja untuk bersaing khususnya di negara ASEAN atau dalam hal ini sering disebut dengan MEA (Masyarakat Ekonomi ASEAN). Oleh sebab itu, untuk menyikapi hal tersebut maka dibutuhkan SDM yang berkualitas tinggi agar dapat bersaing baik di tingkat nasional maupun internasional. Salah satu upaya untuk meningkatkan kualitas SDM yakni melalui jalur pendidikan. Dimana melalui pendidikan ini bertujuan untuk meningkatkan kualitas sumber daya manusia melalui peningkatan pola beripikirnya kepada setiap individu. Selain itu juga melalui proses pendidikan, manusia dapat membentuk ketrampilan dan juga kepribadian yang baik. Negara Indonesia mengaturnya melalui Undang - Undang 20 tahun 2003 pasal 1 ayat 1 yang berbunyi: "pendidikan adalah usaha sadar dan terencana untuk mewujudkan suasana belajar dan proses pembelajaran agar siswa secara aktif mengembangkan potensi dirinya untuk memiliki kekuatan spiritual keagamaan, pengendalian diri, kepribadian, kecerdasan, akhlak mulia, serta keterampilan yang diperlukan dirinya, masyarakat, bangsa dan negara".

Upaya dalam membangun Sumber Daya Manusia yang berkualitas salah satunya dengan menyelenggarakan pendidikan kejuruan atau sekolah menengah kejuruan (SMK). Sekolah Menengah Kejuruan (SMK) merupakan pendidikan pada jenjang menengah yang mengutamakan pengembangan kemampuan siswa untuk melaksanakan jenis pekerjaan tertentu. Pendidikan kejuruan mengutamakan penyiapan siswa untuk memasuki lapangan kerja serta mengembangkan sikap profesional. Hal ini sesuai dengan salah satu tujuan SMK yaitu untuk mengisi tenaga kerja di industri. SMK juga menyelenggarakan program-program pendidikan yang disesuaikan dengan jenis-jenis lapangan kerja (Peraturan Pemerintah No. 29 tahun 1990). Sekolah Menengah Kejuruan (SMK) merupakan salah satu bentuk satuan pendidikan formal yang menyelenggarakan pendidikan kejuruan pada jenjang pendidikan menengah sebagai lanjutan dari SMP, MTs, atau bentuk lain yang sederajat. Sekolah di jenjang pendidikan menengah jenis kejuruan dapat bernama Sekolah Menengah Kejuruan (SMK) atau Madrasah Aliyah Kejuruan (MAK), atau bentuk lain yang sederajat (Undang-Undang Sisdiknas Nomor 20 Tahun 2003).

Tujuan pendidikan menengah kejuruan menurut Undang-Undang Nomor 20 Tahun 2003, memiliki tujuan secara umum dan khusus. Tujuan umum pendidikan menengah kejuruan adalah: (a) meningkatkan keimanan dan ketakwaan peserta didik kepada Tuhan Yang Maha Esa; (b) mengembangkan potensi peserta didik agar menjadi warga negara yang berakhlak mulia, sehat, berilmu, cakap, kreatif, mandiri, demokratis, dan bertanggung jawab; (c) 
mengembangkan potensi peserta didik agar memiliki wawasan kebangsaan, memahami, dan menghargai keanekaragaman budaya bangsa Indonesia; dan (d) mengembangkan potensi peserta didik agar memiliki kepedulian terhadap lingkungan hidup dengan secara aktif turut memelihara dan melestarikan lingkungan hidup, serta memanfaatkan sumber daya alam dengan efektif dan efisien.

Dari ketentuan - ketentuan diatas bahwa dalam proses penyelenggaraan pendidikan menengah merupakan suatu hal yang sangat penting. Dimana keberhasilan pendidikan sekolah menengah kejuruan ini juga bergantung pada proses pembelajaran baik secara teori maupun pembelajaran praktik pada penyelenggaraannya. Pembelajaran yang baik adalah dimana melibatkan peserta didik secara aktif untuk belajar, menarik minat dan perhatian serta meningkatan motivasi peserta didik. Selain itu juga pembelajaran tersebut harus dilakukan secara terstruktur dan sistematis mulai dari persiapan, pelaksanaan, dan evaluasi. Terlebih lagi pada saat ini sudah dituntut untuk menggunakan kurikulum 2013 yang mengedepankan sikap aktif siswa dalam hal kegiatan pembelajarannya. Dengan kurikulum ini kompetensi lulusan yang merupakan kemampuan dalam sikap, pengetahuan, dan ketrampilan dapat direncanakan sebelum pembelajaran, dilaksanakan melalui pembelajaran, dan dikendalikan melalui evaluasi. Bila kurikulum direncanakan dengan baik, dilaksanakan dalam pembelajaran dengan baik, serta selalu dilakukan evaluasi dengan baik, maka lulusan satuan pendidikan akan mempunyai kompetensi yang diharapkan.

Kurikulum 2013 mengembangkan proses pembelajaran dimana mengembangkan pengetahuan, kemampuan berfikir dan ketrampilan psikomotorik melalui interaksi langsung dengan sumber belajar yang dirancang dalam silabus dan RPP berupa kegiatan - kegiatan pembelajaran (Permendikbud 2013). Pembelajaran yang dilakukan adalah berpusat pada siswa (Student Center) sudah tidak lagi guru yang mendominasi dalam kegiatan pembelajarannya. Sehingga kurikulum 2013 ini menunutut siswa untuk aktif belajar dan mencari informasi sebanyak - banyaknya.

SMK N 2 Yogyakarta merupakan sekolah menengah kejuruan berbasis teknologi yang menyiapkan peserta didik untuk bekerja sesuai bidang tertentu dengan kompetensi dan standar kinerja yang dipersyaratkan, dituntut untuk memiliki ketrampilan yang berkualitas dalam memasuki dunia kerja serta mampu mengembangkan sikap profesional. Sesuai dengan visi SMK N 2 Yogyakarta yaitu menjadi Menengah Kejuruan yang berkarakter, berbudaya, berwawasan lingkungan, menghasilkan insan yang bertaqwa, profesional, mampu berwirausaha dan berdaya saing global. Berdasarkan visi SMK N 2 Yogyakarta tersebut diharapkan lulusan SMK N 2 Yogyakarta memliki ketrampilan yang profesional, mampu berwirausaha dan juga 


\section{Faisal Akhmad}

berdaya saing global serta berlandaskan karakter, berbudaya berwawasan lingkungan dan juga menjadi insan yang bertaqwa.

Namun demikian, berdasarkan data hasil UAS di SMK N 2 Yogyakarta pada mata pelajaran PMKR semester ganjil tahun 2018/2019 kelas XI TKR, dari total 31 siswa yang mengikuti UAS hasil rata - ratanya adalah sebesar 59,58. Dari hasil tersebut apabila dibandingkan dengan nilai KKM yang telah ditetapkan, hasilnya belum maksimal atau masih berada dibawahnya. Sedangkan KKM yang telah ditetapkan yakni sebesar 76, yang harapannya seluruh siswa atau dalam persen yakni $100 \%$ memperoleh nilai minimal atau diatas 76 tersebut. Apabila dilihat dalam prosentase ketuntasan hasil belajar siswanya hanya sebesar 3,20\% siswa yang sudah tuntas.

Selain itu juga SMK N 2 Yogyakarta sudah menerapkan kurikulum 2013. Dimana proses pembelajaran pada kurikulum ini sudah berfokus pada peserta didik (Student Center) dan juga proses pembelajaran yang dilakukan sudah menggunakan model - model pembelajaran yang bertujuan untuk meningkatkan keaktifan, hasil belajar, serta membuat suasana belajar yang menyenangkan. Namun berdasarkan observasi yang dilakukan peneliti selama berjalannya PLT, proses pembelajaran yang dilakukan masih terpusat pada guru, yang di mana pembelajaran masih kurang sistematis salah satunya ditunjukan oleh penggunaan metode pembelajaran yang belum dilterapkan secara maksimal.

Selain itu juga Pembentukan pembelajaran berkelompok juga masih konvensional diantaranya masih dibiarkannya siswa yang mendominasi kelompok serta siswa yang menggantungkan diri pada kelompok, keterampilan sosial sering tidak secara langsung diajarkan, dan penekanan pembelajaran sering hanya pada penyelesaian tugas. Selain itu, dalam hal pembelajaran berkelompok masalah yang sering muncul adalah siswa selalu ingin berkelompok dengan teman yang dianggap dekat dengannya yang menyebabkan tidak meratanya pencapaian siswa dalam pembelajaran yang diikutinya.

Rendahnya hasil Nilai UAS di SMK N 2 Yogyakarta ini dipengaruhi oleh banyak faktor. Salah satu faktor yang sangat berpengaruh disini adalah Faktor SDM dalam hal ini adalah guru, karena sebagai aktor utama dalam proses pembealajaran. Peranan guru disini dalam menentukan pola kegiatan pembelajaran di kelas sangat penting dalam menyediakan dan memperkaya pengalaman belajar siswa. Kemudian faktor selanjutnya yang sangat berpengaruh adalah proses dimana meliputi RPP, metode pembelajaran, Media dan juga evaluasinya belum dilaksanakan secara maksimal. Selain itu juga ada faktor psikologi peserta didik yang terdiri dari minat, motivasi, sikap, bakat dan intelegensi. Sedangkan faktor eksternal terdiri dari faktor lingkungan meliputi guru, teman, masyarakat, keluarga, media, dan sekolah. 
Salah satu upaya berdasarkan uraian diatas, maka diperlukan suatu pendekatan pembelajaran yang tepat dan sesuai dengan kondisi dan kebutuhan siswa. Penggunaan pendekatan pembelajaran yang tepat sangat menentukan keberhasilan dari proses belajar mengajar. Dengan pendekatan pembelajaran yang tepat pula, guru dapat membantu siswa dalam mengembangkan keaktifan dan meningkatkan hasil belajar siswanya. Dalam hal pembelajaran, keterlibatan guru dan murid secara aktif didalam kegiatan pembelajaran sangat mempengaruhi hasil belajar siswa. Dimana pembelajaran yang dilaksanakan sesuai dengan Kurikulum 2013 adalah terpusat pada siswa (Student Centered) tidak harus terpusat pada guru.

Salah satu model pembelajaran yang dapat diterapkan adalah model pembelajaran kooperatif tipe Student Teams-Achivements Divisions (STAD). Model pembelajaran ini merupakan model pembelajaran yang mudah untuk diterapkan, yakni menggunakan kelompok belajar secara campuran antara tingkat prestasi, jenis kelamin, dan suku. Pada prinsipnya model pembelajaran ini adalah dengan kerjasama diantara anggota kelompok agar seluruh anggota kelompok dapat menguasai tujuan pembelajaran sehingga dapat meningkatkan hasil belajar siswa.

Pembelajaran kooperatif tipe STAD ini merupakan salah satu tipe dari model pembelajaran kooperatif dengan menggunakan kelompok dengan jumlah anggota 4-5 orang siswa secara heterogen. Diawali dengan penyampaian tujuan pembelajaran, penyampaian materi, kegiatan kelompok, kuis dan penghargaan kelompok Trianto (2014:118). Model pembelajaran STAD berfokus pada siswa dimana menciptakan suasana belajar yang aktif, inovatif dan juga menyenangkan dalam proses pembelajarannya. Selain itu juga model pembelajaran STAD berfokus pada kerjasama kelompok belajar. Hal ini akan menuntut siswa untuk saling membantu, memberi motivasi, dan saling percaya satu sama lain. Pembelajaran yang menekankan pada kerjasama akan memberi kesempatan kepada siswa untuk belajar bekerjasama, berbagi pendapat, pengetahuan, pengalaman, mendengarkan pendapat orang lain, saling memotivasi dan aktif dalam kegiatan pembelajaran.

Sintaks dalam model pembelajaran STAD menjadikan siswa sebagai pusat dalam kegiatan pembelajaran (Student Centered). Adapun langkah - langkah pembelajarannya adalah sebagai berikut menurut Rusman (2012:215-217): 1) Penyampaian tujuan dan motivasi, 2) Membentuk kelompok kooperatif yang dimana terdiri dari antar prestasi, 3) presentasi dari guru, 4) Kegiatan Belajar dalam TIM, 5) Kuis, 6) Penghargaan TIM.

Pembelajaran kooperatif tipe Student Teams Achievement Divisions (STAD) ini mempunyai beberapa keunggulan yang menjadi perbedaan apabila dibandingkan dengan pembelajaran yang sebelumnya. Menurut (Isjoni, dalam Afandi, dkk 2013:73) keunggulan 


\section{Faisal Akhmad}

tersebut yaitu: (1) menekankan pada adanya aktivitas dan interaksi diantara siswa untuk saling memotivasi dan saling membantu dalam menguasai materi pelajaran, (2) setiap siswa memliki kesempatan yang sama dalam hal kegiatan tim dan juga penghargaan tim. Selain itu juga menurut Ibrahim, dkk (Majid,2013:176) menyampaikan perbedaan pembelajaran kooperatif dengan pembelajaran yang masih konvensional sebelumnya yang ditnjukkan pada ciri - ciri pembelajarannya sebagai berikut: (1) siswa bekerja dalam kelompok untuk menuntaskan belajar; (2) pembelajaran kelompok dibentuk dari siswa yang memiliki berbagai ketrampilan; (3) penghargaan lebih berorientasi pada kelompok daripada individu.

Melalui penerapan model pembelajaran yang demikian maka dapat melibatkan siswa terlibat aktif dalam proses pembelajran seperti yang dikemukakan pada keunggulan model pembelajaran tipe STAD ini. Dengan demikian diharapkan mampu meningkatkan hasil belajar siswa pada mata pelajaran Pemeliharaan Mesin Kendaraan Ringan (PMKR) kelas XI TKRO di SMK N 2 Yogyakarta melalui penerapan model pembelajaran kooperatif tipe STAD.

\section{METODE}

Penelitian ini merupakan penelitian Tindakan Kelas (PTK) dengan menerapkan model pembelajaran kooperatif tipe Student Teams Achievement Division (STAD) untuk meningkatkan hasil belajar siswa. Model PTK yang digunakan dalam penelitian ini adalah menggunakan model spiral dari Kemmish dan Mc. Taggart. Penelitian ini dilaksanakan pada 15 Juli 2019 15 Agustus 2015 di SMK N 2 Yogyakarta yang beralamat di Jl. AM. Sangaji No. 47 Yogyakarta.

Subjek dalam penelitian ini adalah siswa kompetensi keahlian TKR kelas XII TKR 3 yang mengikuti mata pelajaran Pemeliharaan Mesin Kendaraan Ringan (PMKR) pada semester ganjil tahun ajaran 2019/2020. Jumlah siswa dalam satu kelas yaitu sebanyak 31 siswa. Pada penelitian ini teknik pengumpulan data menggunakan observasi dan tes. Observasi dilakukan untuk mengamati pelaksanaan model pembelajaran kooperatif tipe STAD. Tes dilakukan untuk mengukur kemampuan pemahaman siswa tentang materi yang sebelumnya disampaikan.

Pada penelitian tindakan kelas ini menggunakan dua macam pengujian yakni validasi konstruk dan validasi isi. Pengujian validitas konstruk dilakukan dengan menggunakan pendapat ahli (Judgment Expert) atau dalam hal ini dosen pembimbing. Sedangkan validasi isi yakni dengan membandingkan antara isi instrumen dengan isi instrumen pada mata pelajaran yang diajarkan. Teknik analisis data yang digunakan dalam penelitian ini meliputi prosentase pelaksanaan model pembelajaran kooperatif tipe STAD, Prosentase ketuntasan kelas, dan rata - rata hasil belajar siswa. Adapun rumus yang digunakan adalah sebagai berikut: 


\section{Prosesntase Pelaksanaan Model Pembelajaran Koopertaif Tipe STAD (\%)}

$$
=\frac{\text { Jumlah poin terlaksana }}{\text { Jumlah seluruh poin }} \times 100 \%
$$

Ketuntasan Kelas (\%)

$$
=\frac{\text { jumlah siswa KKM }}{\text { total siswa }} \times 100 \%
$$

Rata - rata hasil belajar

$$
\overline{\mathrm{x}}=\frac{\sum \mathrm{x}}{\mathrm{n}}
$$

\section{HASIL DAN PEMBAHASAN}

\section{Hasil Penelitian}

1) Pelaksanaan Model Pembelajaran Kooperatif Tipe STAD

Penelitian Tindakan Kelas ini dilaksanakan sebanyak dua siklus yang selalu dilakukan pengamatan terkait pelaksanaan pembelajaran dengan model pembelajaran kooperatif tipe STAD. Adapun hasil prosentase dari keterlaksanaan model pembelajaran kooperatif tipe STAD adalah sebagai berikut:

Tabel 1.Prosentase Pelaksanaan Model Pembelajaran Kooperatif Tipe STAD

\begin{tabular}{lll}
\hline No & Pelaksanaan & Hasil (\%) \\
\hline 1 & Siklus I & 70 \\
2 & Siklus II & 100 \\
\hline
\end{tabular}

Apabila dilihat dalam bentuk grafik prosentase pelaksanaan model pembelajaran kooperatif tipe STAD adalah sebagai berikut: 


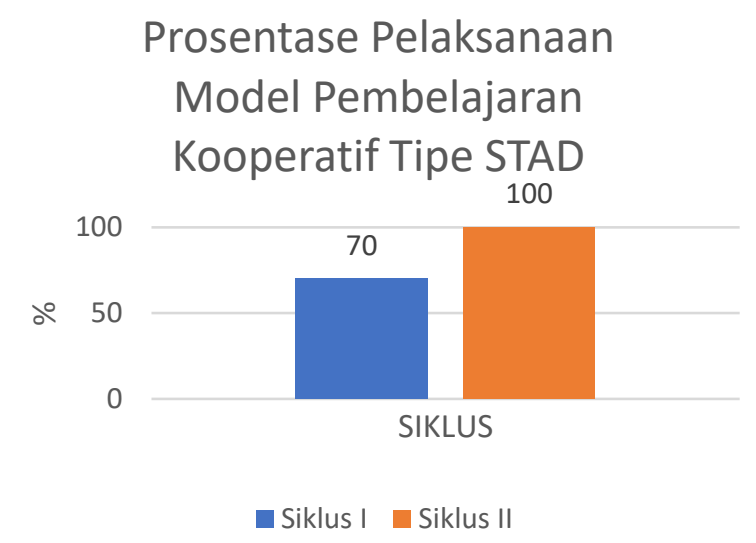

Gambar 1. Grafik Persentase Pelaksanaan Model Pembelajaran Kooperatif tipe STAD

2) Hasil Belajar Siswa

Hasil belajar siswa yang diperoleh pada penelitian ini yang diambil dari nilai post-test yang dilakukan diakhir siklus II adalah sebagai berikut:

Tabel 2. Pencapaian Hasil Belajar Siswa

\begin{tabular}{llll}
\hline No & Hasil Belajar & $\begin{array}{l}\text { Data } \\
\text { Awal }\end{array}$ & Data Akhir \\
\hline 1 & Tertinggi & 80 & 100 \\
2 & Terendah & 43 & 68 \\
3 & KKM & 76 & 76 \\
4 & Lulus KKM & 1 & 28 \\
5 & Belum Lulus KKM & 30 & 3 \\
6 & Rerata & 59,58 & 88,52 \\
7 & Persentase ketuntasan kelas & $3,20 \%$ & $90,30 \%$ \\
\hline
\end{tabular}

3) Penghargaan Kelompok

Penelitian tindakan kelas ini adalah penelitian yang dilakukan dengan menerapkan model pembelajaran kooperatif tipe STAD untuk meningkatkan hasil belajar siswa. Disamping didapatkan hasil belajar siswa pada penelitian ini juga didapatkan hasil penghargaan kelompok yang merupakan salah satau ciri dari model pembelajaran yang diterapkan. Adapun hasil penghargaan kelompok yang diberikan adalah sebagai berikut:

Tabel 3. Penghargaan Kelompok

\begin{tabular}{lll}
\hline Kelompok & Rata - rata & $\begin{array}{l}\text { Penghargaan } \\
\text { Kelompok }\end{array}$ \\
\hline 1 & 30 & Super \\
2 & 30 & Super \\
3 & 28 & Super \\
4 & 30 & Super \\
5 & 30 & Super
\end{tabular}




\begin{tabular}{lll}
6 & Super \\
\hline
\end{tabular}

\section{Pembahasan}

1) Pelaksanaan Model Pembelajaran Kooperatif Tipe STAD

Pada penelitian ini dilakukan sebanyak dua siklus yang selalu dilakukan pengamatan terkkait pelaksanaan pembelajaran menggunakan model pembelajaran kooperatif tipe STAD.

Siklus I pelaksanaan model pembelajaran kooperatif tipe Student Teams Achievement Division (STAD) prosentase pelaksanaanya adalah 70\%. Berdasarkan hasil tersebut pelaksanaan pembelajaran belum berjalan dengan maksimal dikarenakan guru dan siswa belum terbiasa dengan model pembelajaran kooperatif tipe STAD sehingga memerlukan penyesuaian.

Siklus II dilaksanakan berdasarkan hasil refleksi dari siklus sebelumnya sehingga dapat berjalan dengan baik dan maksimal. Hal tersebut dibuktikan berdasarkan prosentase pelaksanaan model pembelajaran STAD yakni sebesar 100\%, artinya keberhasilan pelaksanaan model pembelajaran tersebut dapat terlaksana. Pada siklus II pelaksanaan pembelajaran kooperatif tipe STAD sudah baik dan maksimal, terbukti dari poin pelaksanaan pada lembar observasi yang sudah terpenuhi semua.

Penelitian ini adalah untuk meningkatkan hasil belajar siswa kelas XI TKR di SMK N 2 Yogyakarta pada mata pelajaran PMKR melalui penerapan model pembelajaran kooperatif tipe Student Teams Achievement Division (STAD). Model pembelajaran STAD ini merupakan pembelajaran kelompok yang menekankan kerjasama antar anggota kelompok untuk memahami pelajaran sehingga tujuan pembelajaran dapat tercapai. Dengan pelaksanaan model pembelajaran kooperatif tipe Student Teams Achievement Division (STAD) yang sudah baik dan maksimal harapannya mampu meningkatkan hasil belajar siswa. Hasil belajar siswa dijadikan sebagai acuan peningkatan pemahaman siswa terkait materi pembelajaran yang diajarkan.

\section{2) Hasil Belajar Siswa}

Hasil belajar siswa merupakan permasalahan yang menjadi fokus utama dalam penelitian ini. Melalui penelitian ini bermaksud untuk meningkatkan hasil belajar siswa melalui penerapan model pembelajaran koopertaif tipe Student Teams Achievement Division (STAD).

Berdasarkan data observasi, hasil belajar setelah dikenai tindakan adalah meningkat. Pada data awal yang diperoleh hasil belajar siswa rata - ratanya adalah 59,58 dengan nilai tertinggi sebesar 80 dan nilai terendah 43. Pelaksanaan model pembelajaran kooperatif tipe STAD pada siklus I belum maksimal dalam pelaksanaannya sehingga penilaian hasil belajar belum 


\section{Faisal Akhmad}

dapat dilakukan. Selain itu juga pada siklus I masih terdapat beberapa kendala yang kemudian dijadikan refleksi untuk pertemuan berikutnya. Kemudian siklus II dilaksanakan berdasarkan hasil perbaikan atau refleksi dari siklus sebelumnya sehingga rata - rata hasil belajar didapatkan 88,52 dengan nilai tertinggi adalah 100 dan nilai terendah 62. Dengan hasil yang demikian maka dapat dilihat bahwa hasil belajar siswa meningkat karena penerapan model pembelajaran kooperatif tipe Student Teams Achievement Division (STAD) yang sudah maksimal.

Apabila dilihat dari jumlah siswa yang mencapai KKM 76 juga menunjukkan peningkatan. Pada data awal prosentase ketuntasan kelas adalah sebesar 3,20\% atau sebanyak 1 siswa kemudian setelah dikenai tindakan mengalami kenaikan menjadi 90,30\% atau sebanyak 28 siswa sudah tuntas. Karena target ketuntasan kelas adalah 75\% maka siklus dihentikan cukup sampai siklus II. Apabila dilihat dalam bentuk adalah sebagai berikut:

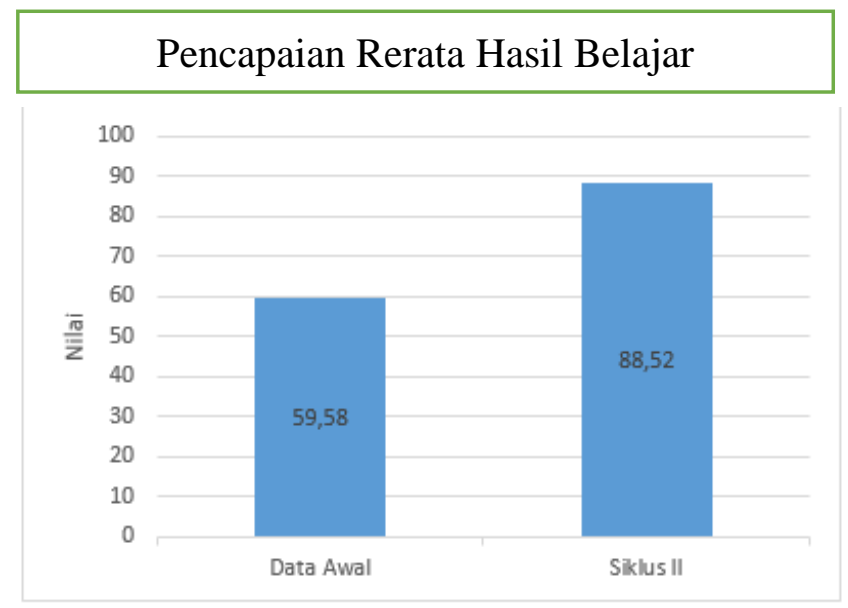

Gambar 2. Grafik Pencapaian Rerata Hasil Belajar.

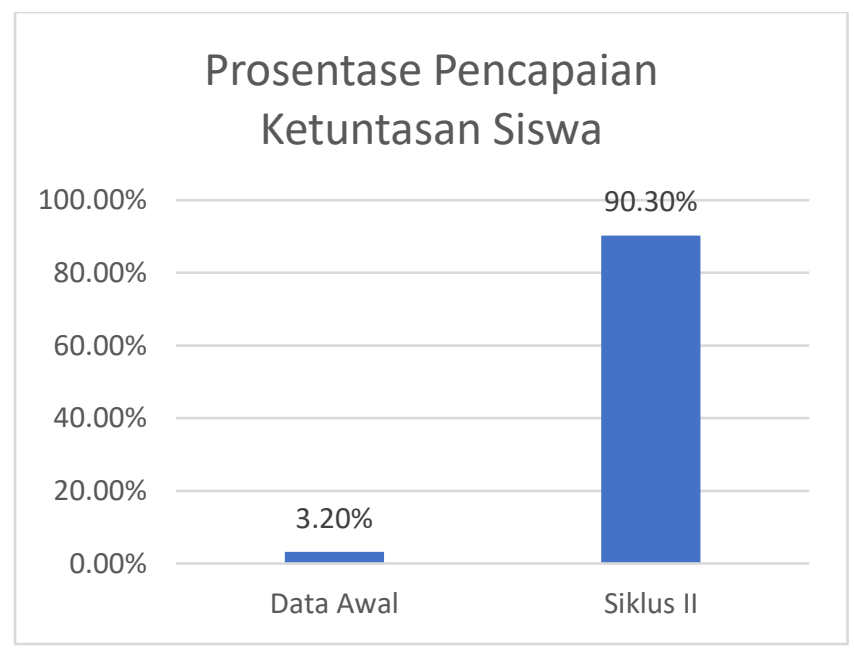

Gambar 3. Diagram Pencapaian Ketuntasan Hasil Belajar siswa

3) Keberhasilan Penerapan Model Pembelajaran Kooperatif tipe STAD untuk Meningkatkan Hasil Belajar Siswa 
Berdasarkan hasil penelitian ini menunjukan bahwa penerapan model pembelajaran kooperatif tipe Student Teams Achievement Division (STAD) pada mata pelajaran Pemeliharaan Mesin Kendaraan Ringan (PMKR) kelas XI TKR di SMK N 2 Yogyakarta dapat meningkatkan hasil belajar siswa.

Hasil belajar siswa pada siklus I belum terlaksana karena pelaksanaan pembelajaran dengan menggunakan model pembelajaran STAD belum terlaksana secara maksimal. Prosentase keterlaksanaan tindakan pada siklus I adalah sebesar 70\%. Siklus II dilaksanakan berdasarkan perbaikan hasil refleksi pada siklus sebelumnya sehingga pelaksanaan pembelajaran dapat berjalan secara maksimal. Berdasarkan hasil yang didapatkan prosentase pelaksanaannya sudah $100 \%$, hasil belajar siswa pun meningkat dengan prosentase ketuntasan kelasnya adalah sebesar $90,30 \%$ siswa.

Penerapan model pembelajaran kooperatif tipe Student Teams Achievement Division (STAD) pada mata pelajaran Pemeliharaan Mesin Kendaraan Ringan (PMKR) kelas XI TKR di SMK N 2 Yogyakarta berdasarkan hasil penelitian ini dapat meningkatkan hasil belajar siswa. Beberapa hasil penelitian ini juga mendukung penelitian yang relevan, yaitu Penerapan model pembelajaran kooperatif tipe STAD dapat meningkatkan keaktifan dan hasil belajar pada mata pelajaran PKKR kelas XI SMK Piri Sleman (Kurniawan L.T:2018). Hasil penelitian ini juga sejalan dengan penelitian (Kristanto Ignasius:2018) yang menunjukan bahwa hasil penelitian dapat meningkatkan hasil belajar siswa pada mata pelajaran TDO. Selain itu mendukung juga penelitian yang dilakukan (Lasera A.B:2018) yang hasil penelitian menunjukan bahwa penerapan model pembelajaran koopertaif tipe STAD dapat meningkatkan keaktifan dan hasil belajar siswa pada mata pelajaran prakarya dan kewrausahaan rekayasa kelas X/IIK MAN Temanggung.

\section{SIMPULAN}

Berdasarkan pada hasil dan pembahasan penelitian, maka dapat disimpulkan bahwa penerapan model pembelajaran kooperatif tipe Student Teams Achievement Division (STAD) pada mata pelajaran Pemeliharaan Mesin Kendaraan Ringan (PMKR) kelas XI TKR di SMK N 2 Yogyakarta mampu meningkatkan hasil belajar siswa. Dibuktikan dari hasil penelitian pada data awal yakni prosentase ketuntasan siswa sebelum diterapkan model pembelajaran kooperatif tipe STAD adalah sebesar 3,20\% kemudian setelah diterapkan model pembelajaran kooperatif tipe STAD meningkat menjadi 90,30\%. Apabila dilihat dari rata rata hasil belajar yang dicapai adalah sebagai berikut, pada data awal rata - rata hasil belajar siswa adalah 59,58 kemudian meningkat menjadi 88,52 setelah diterapkan model pembelajaran kooperatif tipe 
46 Faisal Akhmad

STAD. Sedangkan untuk Kriteria Ketuntasan Minimal (KKM) yang ditetapkan adalah sebesar 76.

Berdasarkan hasil penelitian dan pembahasan terdapat beberapa saran yang diajukan:

1. Model pembelajaran kooperatif tipe Student Teams Achievement Division (STAD) yang telah diterapkan di kelas XI TKR di SMK N 2 Yogyakarta dapat djadikan alternatif pembelajaran Pemeliharaan Mesin Kendaraan Ringan (PMKR) untuk meningkatkan hasil belajar siswa.

2. Sebaiknya guru mengembangkan kemampuannya dalam mengajar dengan cara menggunakan variasi dalam pembagian kelompoknya. Seperti yang telah dilaksanakan pada penelitian ini yakni pembagian kelompok berdasarkan prestasi dengan anggota kelompok yang terdiri dari prestasi yang berbeda - beda, sehingga dirasa lebih efektif dan memberikan hasil yang maksimal.

3. Memberikan akses kepada siswa untuk mengeksplor sumber belajar dari berbagai sumber salah satunya internet. Penggunaan handphone pada saat proses diskusi bertujuan untuk mencari sumber belajar, namun guru juga tetap harus mengawasi penggunaan handphone siswa agar tidak terjadi dampak negatif didalam proses diskusi.

4. Hendaknya guru menyiapkan pembelajaran dengan matang, terutama topik diskusi dan sumber belajar yang akan digunakan.

\section{DAFTAR PUSTAKA}

Afandi, Muhamad, dkk. (2013). Model dan Metode Pembelajaran di Sekolah. Semarang: UNISSULA Press.

Depdikbud. (2003). Undang - undang RI Nomor 20, Tahun 2003, tentang Sistem Pemdidikan Nasional.

Gunadi, Usman. T., \& Nugraha. B. S. (2014). Identifikasi Kompetensi SMK Program Studi Otomotif dalam Rangka Implementasi Kebijakan Kurikulum 2013. Jurnal Pendidikan Teknologi dan Kejuruan. from doi: https://doi.org/10.21831/jptk.v22i2.8923.

Kristanto, Ignasius. (2017). Penerapan model Pembelajaran Kooperatif Tipe Student TeamsAchivements Divisions (STAD) Untuk Meningkatkan Hasil Belar Siswa Pada Mata Pelajaran Teknologi Dasar Otomotif(TDO) Kelas X Di SMK Ma'arif Salam. Tugas Akhir Skripsi UNY.

Kurniawan, LT. (2018). Penerapan Model Pembelajaran Kooperatif Tipe STAD Untuk Meningkatkan Keaktifan dan Hasil Belajar Peserta Didik Pada Mata Pelajaran Pemeliharaan Kelistrikan Kendaraan Ringan Di SMK Piri Sleman. TAS.UNY. 
Lasera, AB. (2018). Upaya Meningkatkan Keaktifan dan Hasil Belajar Siswa Melalui Model Pembelajaran Cooperative Learning Tipe STAD Pada Mata Pelajaran Prakarya dan Kewirausahaan Rekayasa kelas XII/K Tahun 2017/2018 MAN Temanggung. TAS.UNY. Majid,Abdul (2013). Strategi Pembelajaran. Bandung: PT Remaja Rosdakarya Offset.

Ramadhan. F. E., \& Suyanto. W. (2019). Implementasi Metode Pembelajaran Two Stay Two Stray Untuk Meningkatkan Keaktifan dan Hasil Belajar Teknologi Dasar Otomotif Siswa Kelas X TKRB SMKN 1 Sedayu. Jurnal Pendidikan Vokasi Otomotif, 1 (2), from doi: https://doi.org/10.21831/jpvo.v1i2.24300.

Rusman. (2012). Model - model Pembelajaran. Jakarta: Raja Grafindo Persada.

Trianto. (2014). Mendesain Model Pembelajaran Inovatif, Progresif dan Kontekstual. Jakarta: Kencana. 
48 Faisal Akhmad 